\title{
Ascensão e queda do pacto populista em Cuba, 1934-1959.
}

\author{
Gillian McGillivray ${ }^{2}$
}

O regime que pôs fim aos "100 dias de reforma” em Cuba é rotulado com frequência como "contrarrevolução" quando, na verdade, a expressão mais apropriada seria a de "populismo autoritário". O novo regime não reverteu a Revolução de 1933; muito pelo contrário, suas lideranças valeram-se da violência combinada com reformas revolucionárias como forma de incorporar, de maneira compulsória, um número cada vez maior de pessoas em um novo e ampliado sistema estatal de liderança. Fulgencio Batista recebeu o apoio de parte da classe trabalhadora ao longo do período democrático que vigorou durante a Segunda Guerra Mundial, mas o anticomunismo da Guerra Fria desestabilizou seu regime, esvaziando o populismo cubano de grande parte da sua substância.

Palavras-chave: Revolução, populismo, classe trabalhadora.

\section{The Rise and Fall of Cuba's Populist Compact, 1934-1959}

The regime that ended Cuba's "100 days of reform" is often labeled a "counter-revolution", although "authoritarian populism" would be a better term. The new regime did not reverse the 1933 Revolution; instead, its leaders used violence combined with revolutionary reforms as a means to forcibly incorporate more people into a newly expanded state system of rule. Fulgencio Batista won some working-class support during the WWII democratic era, but Cold War anticommunism destabilized his regime by emptying Cuba's populism of much of its substance.

Keywords: Revolution, populism, working-class

1 Artigo recebido em 15.3.2012 e aprovado para publicação em 25.5.2012.

2 Glendon College, Departamento de História, Universidade de York. 


\section{L'essor et la chute du pacte populiste à Cuba, 1934-1959}

Le terme "contre-révolution" est souvent utilisé par les historiens de Cuba pour caractériser la période d'après la Révolution de 1933, mais il serait mieux, dans ce cas, de parler de "populisme autoritaire". Les dirigeants du nouveau régime associèrent violence et réformes révolutionnaires pour intégrer par la force des couches de la population dans un système de domination étatique dont le domaine d'intervention prenait alors de l'ampleur. Fulgencio Batista parvint à obtenir l'appui de la classe ouvrière durant la période démocratique qui suivit la fin de la Deuxième Guerre Mondiale, mais la vague anticommuniste de la Guerre froide, finit par vider le Pacte populiste d'une bonne partie de sa substance Mots-clés: Révolution, populisme, classe ouvrière.

No dia 15 de janeiro de 1935, um ano após sua instalação, o regime de Carlos Mendieta-Fulgencio Batista promulgou um decreto-lei que previa pena de prisão perpétua ou pena de morte para qualquer cidadão culpado de crime de incêndio intencional ou de qualquer dano causado às plantações de cana-de-açúcar, às usinas ou aos equipamentos usados no transporte da cana. O mesmo decreto-lei autorizava também o julgamento sumário, como criminoso de direito comum, de qualquer pessoa culpada de "propaganda subversiva" que participasse de greves de solidariedade, ou que reivindicasse dos patrões novas condições de trabalho, durante um período de seis meses após a última greve. Os ativistas trabalhistas eram tidos como revolucionários se deixassem de seguir ao pé da letra os rígidos procedimentos estabelecidos para novas greves. O regime criou também Tribunais da Defesa Nacional para julgar e condenar todos os suspeitos. ${ }^{3}$

Em resposta, os trabalhadores do setor da cana-de-açúcar arquitetaram novas formas de sabotagens clandestinas. Em março de 1936, um grande surto de incêndios propositais que destruiu cerca de 42 mil toneladas de cana desencadeou uma investigação secreta da polícia nas usinas de Chaparra e Delicias. Os

3 Decreto-Lei n ${ }^{\circ} 813$, assinado pelo presidente Carlos Mendieta e pelo secretário de Justiça Raúl de Cárdenas, Gaceta Oficial, Santiago, Gobierno Provincial, n. 3 (extraordinária), 15 jan. 1935, legajo 312, exponiente 10 [daqui por diante, STGO, GP, leg., exp.]. O decreto-lei que criou os "Tribunais de Defesa Nacional" foi promulgado no dia 6 de março de 1934. BUELL, Raymond Leslie et al. Problems of the New Cuba: report of the Commission on Cuban Affairs. Nova York: Foreign Policy Association, 1935. p. 15-16, 202-203. Joanna Beth Swanger descreve a atuação desses tribunais, no que se refere aos trabalhadores das plantações de café, na obra Lands of rebellion: Oriente and Escambray, Encountering Cuban State Formation, 1934-1974. Dissertação (PhD) - Universidade do Texas, Austin, 1999. 
perpetradores haviam aparentemente usado o método do pano queimado: um pedaço de pano embebido em gasolina, colocado no centro de uma clareira, sob uma camada de folhas de cana, e depois aceso. O fogo levava certo tempo para atingir os renques de cana-de-açúcar, o que permitia que o incendiário abandonasse a área sem deixar traços. ${ }^{4}$ Alguns trabalhadores desempregados haviam incendiado o canavial por desespero, acreditando que seriam recontratados, já que a cana precisa ser moída no prazo de 48 horas para não perder seu teor de sacarose. Outros usaram esse meio como forma de sabotagem para contrapor-se à repressão que lhes havia deixado poucas opções.

Os meios utilizados para combater a repressão incluíam greves em todo o território da Ilha, assassinatos e explosões de bombas nas cidades e atos de sabotagem no interior do país. Embora o regime Mendieta-Batista - que havia posto fim aos "100 dias de reforma” do presidente Ramón Grau San Martin e do ministro do Interior Antonio Guiteras - seja rotulado como "contrarrevolução", o presente artigo sustenta que, na verdade, o rótulo de "populismo autoritário" seria o que melhor caberia a esse regime. ${ }^{5} \mathrm{O}$ novo regime não reverteu o sentido da Revolução de 1933. Muito pelo contrário, seus líderes valeram-se de meios violentos, associados a reformas revolucionárias, como forma de incorporar compulsoriamente mais e mais pessoas a um sistema estatal ampliado de governo. Mendieta, na esperança de ampliar sua base de apoio, qualificou de conservadoras a maior

4 "Relatório" do agente da polícia secreta Francisco Micó Urrutia sobre o incêndio nos canaviais de Chaparra e Delicias, encaminhado por Rafael Balart Perera, chefe da Polícia Secreta em Santiago, ao governador de Santiago em 22 de março de 1936, STGO, GP, leg. 312, exp. 16.

5 Robert H. Dix (Populism: authoritarian and democratic. Latin American Research Review, v. 20, n. 2, p. 29-52, 1985) cunhou as expressões "populismo autoritário" e "populismo democrático", mas não incluiu Cuba nesse debate. Procurei defini-las de forma mais cuidadosa com a metáfora corporativista do corpo, como abaixo. A literatura sobre o populismo na América Latina é volumosa. Entre os autores que mais me inspiraram neste estudo estão FRENCH, John. Workers and the rise of adhemarista populism in São Paulo, Brazil, 1945-1947. Hispanic American Historical Review, v. 68, n. 1, p. 1-43, fev. 1988; GOULD, Jeffrey. To lead as equals: rural protest and political consciousness in Chinandega, Nicaragua, 1912-1979. Chapel Hill: University of North Carolina Press, 1990; JAMES, Daniel. Resistance and Integration: peronism and the Argentine Working Class, 1946-1976. Cambridge: Cambridge University Press, 1988; TURITS, Richard. Foundations of despotism: peasants, the Trujillo regime, and modernity in dominican history. Stanford: Stanford University Press, 2003; ADELMAN, Jeremy. Andean impasses. New Left Review, n. 18, p. 41-72, nov./dez. 2002; e GRANDIN, Greg. The last colonial massacre: Latin America in the Cold War. Chicago: University of Chicago Press, 2004. 
parte das reformas de Grau e de Guiteras. ${ }^{6}$ Entretanto, o período de governo de Mendieta não passou de um ano de vida, e a segunda parte deste artigo mostrará as parcas chances que Batista tinha de obter o apoio da classe dos trabalhadores até que o "pacto populista" começou a se aprofundar durante a era democrática que envolveu a Segunda Guerra Mundial.

Um olhar mais cuidadoso sobre o período de dominação de Batista, nas décadas de 1930 e 1940, mostra que ele não era muito diferente dos outros populistas autoritários que tomaram o poder na era da Depressão dos anos 1930, como Anastásio Somoza na Nicarágua, ou Rafael Trujillo na República Dominicana. É fato que esses líderes sustentavam-se fortemente no Exército como base para seu poder, mas é também fato que eles fizeram esforços concertados para obter o apoio de grupos populares como trabalhadores e camponeses, e que trouxeram alguns benefícios às pessoas que se filiaram às associações e aos sindicatos apoiados pelo Estado. O regime Mendieta-Batista pode ser chamado de "populista" por ter-se esforçado de maneira genuína a dar mais atenção às necessidades do povo mediante a atuação de novas instituições governamentais como o Ministério do Trabalho ou o Instituto Cubano de Estabilização do Açúcar (ICAE), de um lado - e dos sindicatos oficiais (para trabalhadores) e associações (para os produtores de cana e usineiros). Contudo, o elemento "autoritário" do regime não pode deixar de ser destacado, já que lançou mão da força militar para esmagar todas as alternativas independentes. O populismo é sempre uma combinação de força e persuasão, mas, em 1934, Mendieta e Batista priorizaram o uso da força para conter a mobilização das massas da Revolução de 1933 e atrair seus participantes no rumo de um novo Estado populista.

O México, sob Lázaro Cárdenas na década de 1930, fornece o exemplo mais contundente desse modelo "democrático populista", mas Cuba editou versões ainda mais desprovidas de conteúdo desse modelo durante a presidência de Batista, de 1940 a 1944, e durante as presidências do Partido Auténtico sob

6 DOMíNGUEZ, Jorge. Cuba: order and revolution. Cambridge, Mass.: Belknap Press, 1978. p. 78-79. A primeira parte deste artigo traz ideias de Domínguez, no detalhado estudo de Whitney sobre as décadas de 1930 e de 1940, em WHITNEY, Robert. State and revolution in Cuba: mass mobilization and political change, 1920-1940. Chapel Hill: University of North Carolina Press, 2001. caps. 6-7, e de PÉREZ JR., Louis A. Army politics in Cuba, 1898-1958. Pittsburgh: University of Pittsburgh Press, 1976. 
Grau San Martin (1944-1948) e Carlos Prío Socarrás (1948-1952). ${ }^{7}$ No modelo de "populismo autoritário" os militares compartilham a condução do Estado com o presidente, como ocorreu durante o regime apropriadamente chamado de Regime Mendieta-Batista (1934-1935), e durante alguns anos do governo de Juán Perón na Argentina e de Getúlio Vargas no Brasil.

O presente artigo mostra que o anticomunismo da Guerra Fria, de 1947 a 1959, esvaziou o pacto populista de Cuba de grande parte de sua substância. Em Havana e nas comunidades das usinas de cana, somente os líderes e chefes das agências locais de órgãos coletivos, como a Confederação de Trabalhadores Cubanos (CTC) e a Associação Nacional de Plantadores de Cana, recebiam vantagens do regime. Por isso, as vantagens não eram suficientes para manter os demais participantes satisfeitos. Um menor número de beneficiários significava também menor apoio ao regime, o que explica por que o presidente e os usineiros começaram a valer-se cada vez mais do apoio do Exército para manter a ordem. Esse processo, entre outros problemas, tais como o desemprego e a estagnação econômica (ligados à economia da monocultura da cana-de-açúcar), acabou contribuindo para o triunfo da Revolução de 1959. Estamos tratando aqui dos produtores de cana e trabalhadores das usinas, pois os "grupos lobistas" que apoiavam ou se opunham aos regimes das décadas de 1930, 1940 e 1950 já estavam, ao mesmo tempo, constituindo-se entre os militares, no setor da educação e entre os quadros profissionais. ${ }^{8}$

\section{A alvorada de um novo pacto: o populismo autoritário, 1934-1936}

Para poder entender o sistema de governo populista autoritário, precisamos estudar seus líderes: Carlos Mendieta e Fulgencio Batista. Mendieta, oriundo

7 Para um exame do caso de Cárdenas no México, ver CÓRDOVA, Arnaldo. La politica de masas del cardenismo. Cidade do México: Era, 1986; e HAMILTON, Nora. The limits of State autonomy: post-revolutionary Mexico. Princeton: Princeton University Press, 1982. Essas obras focalizam o "quadro geral"; outros estudos mais recentes examinam os efeitos complexos do governo populista de Cárdenas nas províncias.

8 Para mais informações sobre esses outros grupos, ver DOMÍNGUEZ. Cuba; PATERSON, Thomas G. Contesting Castro: the United States and the triumph of the Cuban revolution. Nova York: Oxford University Press, 1994; SUCHLICKI, Jaime. University students and revolution in Cuba, 1920-1968. Coral Gables: University of Miami Press, 1969; WHITNEY. State and revolution in Cuba; e PÉREZ, Army and politics in Cuba, que fornecem uma análise bem-estruturada das classes médias, da mesma forma que outras análises realizadas pelo presente autor. 
da província central de Las Villas (assim como os presidentes Miguel Gómez, 1909-1912, e Gerardo Machado, 1925-1933), pertencia à elite cubana e era um veterano da Guerra da Independência. ${ }^{9}$ Membro influente do Partido Liberal, Mendieta havia concorrido à presidência do país em 1924, tendo sido, entretanto, derrotado por Machado. Em 1931, formou a Unión Nacionalista juntamente com o antigo presidente conservador Mario García Menocal (1912-1921), mas sua rebelião de "Rio Verde", naquele mesmo ano, não logrou destituir o presidente Machado do poder.

Ao se tornar presidente, em janeiro de 1934, Mendieta promulgou uma nova Constituição para o país, concedeu anistia política a muitas pessoas e refreou o tratamento brutal dado aos prisioneiros. ${ }^{10}$ Promulgou diversas leis, de 1934 a 1935, entre as quais a autorização de um pedido oficial do governo para que os políticos americanos reconhecessem a abolição, por Grau, da Emenda Platt, a confirmação do voto das mulheres e a ampliação do sistema de seguridade social. Em benefício dos trabalhadores, Mendieta reforçou a legislação sobre a jornada de oito horas de trabalho e aprovou uma legislação sobre os contratos de trabalho. Esses contratos se aplicavam a todos os empregados e trabalhadores de determinada empresa, contrapondo-se, assim, ao sistema de "dividir para conquistar" muito utilizado pelas empresas. Declarou a ilegalidade da demissão sem justa causa de trabalhadores e tornou o procedimento para sua demissão mais complicado, constituindo-se, assim, em proteção aos trabalhadores. Mendieta criou também uma Comissão de Salário Mínimo, composta por representantes dos trabalhadores e das empresas, e concedeu um aumento de impressionantes 80\% do salário mínimo para os trabalhadores do campo (em comparação com a média de $20 \%$ de 1933). Garantiu às mulheres "salários iguais para o mesmo trabalho" e promulgou uma Lei sobre a Maternidade, dando, assim, o primeiro passo em direção a um sistema de seguridade do trabalhador. O benefício de férias pagas seguiu-se imediatamente às conquistas anteriores.

Mendieta tencionava provavelmente manter o país em um caminho reformista moderado - o objetivo da Revolução -, mas, em 1933, desencadeou-se uma

9 Como tantos outros cubanos da elite, ele se juntou tardiamente à Guerra da Independência 1895-1898, após a intervenção dos Estados Unidos, quando já se podia assegurar que os cubanos triunfariam sobre os espanhóis.

10 DOMÍNGUEZ. Cuba, p. 78. 
onda de greves que se alastrou de forma exponencial, e o ciclo agrícola do açúcar obrigou-o a tomar as medidas que se faziam necessárias para que a colheita de 1934 se iniciasse o mais rapidamente possível (o açúcar regia a economia cubana e constituía $80 \%$ das exportações do país). No dia 21 de janeiro, Mendieta pôs fim à intervenção do governo nas usinas Chaparra e Delicias e devolveu-as à Cuban-American Sugar Company (daqui por diante denominada "Cubanaco"), sob a condição de iniciarem imediatamente a colheita. Para poder implementar essa transferência à Cubanaco e estabelecer a ordem necessária em toda a Ilha para que a colheita se processasse normalmente, Mendieta pediu ajuda a Batista e a seu Exército. ${ }^{11}$

É difícil interpretar Batista, assim como os demais populistas "autoritários" que assumiram o poder nos anos $1930 .{ }^{12}$ Nascido de uma humilde família de raça mestiça da usina de açúcar do enclave oriental da United Fruit Company - no espectro socioeconômico oposto ao da família espanhola de Fidel Castro, que subarrendava terras aos fazendeiros que vendiam cana à United Fruit -, Batista trabalhou como cortador de cana, carpinteiro, alfaiate e ferroviário antes de ingressar no Exército como estenógrafo em 1921, sendo promovido a sargento em $1928 .{ }^{13} \mathrm{Na}$ decisiva tarde de 3 de setembro de 1933, ele era apenas um dos membros do grupo de sargentos, cabos e soldados que se reuniu na caserna da Camp Columbia em Havana para elaborar uma lista de demandas ligadas a necessidades básicas, como alojamento, alimentação, uniformes, pagamento e acesso a promoções. Quando os oficiais de serviço recusaram-se a levar a petição aos oficiais comandantes, o grupo de militares insatisfeitos enviou delegados

11 Mendieta pôs fim à intervenção governamental em Chaparra e Delicias, mas consolidou também os procedimentos legais para futuras intervenções do Estado em empresas privadas, quando o interesse público fosse prejudicado pela intransigência daquelas empresas. ZANETTI, Oscar. The workers' movement and labor regulation in the Cuban sugar industry. Cuban Studies, n. 25, p. 189191, 1995; SIMS, Harold D. Cuba's organized labor, from Depression to Cold War. Maclas Latin American Essays, n. 11, p. 46, 1997.

12 Com relação a Anastasio Somoza da Nicarágua, ver GOULD. To lead as equals, WALTER. The regime of Anastasio Somoza. Sobre Rafael Trujillo da República Dominicana, ver DERBY. The dictator's seduction: politics and popular imagination in the era of Trujillo. Durham: Duke University Press, 2009, e TURITS. Foundations of despotism.

13 Ao usar a expressão "raça mestiça", os observadores querem sugerir, de maneira geral, que Batista tinha ascendência chinesa, indígena ou afro-cubana. Ver ARGOTE-FREYRE, Frank. Fulgencio Batista: from revolutionary to strongman. New Brunswick, N.J.: Rutgers University Press, 2006; WHITNEY. State and revolution in Cuba, p. 122. 
a outros grupos militares de Havana para obter seu apoio. Ao raiar da manhã seguinte, todos os oficiais haviam deixado Camp Columbia, por considerarem que o protesto dos sargentos e cabos era um ato de amotinação. ${ }^{14}$

No dia 4 de setembro, diversos grupos de oposição se aliaram aos sargentos, legalizando, assim, o ato de amotinação, transformando-o em ato político. Os "sargentos" comprometeram-se a apoiar os objetivos políticos, econômicos e sociais dos civis, mas sua lealdade foi temporária. No dia 8 de setembro, Batista reivindicou e conseguiu o posto de comandante do Exército, conquistando, assim, o direito de nomear oficiais. Em fins de 1933, ele já tinha removido os oficiais leais a Machado e nomeado cerca de 400 novos oficiais (a maioria deles oriundos do círculo de sargentos). Os batistianos substituíram os machadistas no comando das forças armadas. Essa reviravolta significou uma mudança radical no seio das forças armadas: uma grande parte de oficiais não brancos substituiu o corpo de oficiais brancos comprometidos com a elite política da Ilha. ${ }^{15}$

Não ficou imediatamente claro quais segmentos da sociedade iriam ser apoiados pelo Exército batistiano. Vemos aqui a repetição de um padrão: a Revolução de 1933, como, aliás, muitas outras revoluções latino-americanas, começou com líderes da classe média - o que incluía estudantes, profissionais e intelectuais que assumiram o poder aliando-se perigosamente a elementos descontentes da classe militar. Os soldados de Machado haviam abandonado seu comandante em chefe porque este só favorecia os oficiais mais próximos. O restante do Exército sofria as consequências da fúria dos civis contra os militares sem obter com isso qualquer vantagem. Essa dinâmica esteve presente na destituição de várias ditaduras de longo fôlego na América Central e no Caribe, inclusive na de Machado (1925-1933), na de Maximiliano Hernández Martínez em El Salvador (19311944) e na de Jorge Ubico na Guatemala (1931-1944). ${ }^{16}$ O tipo de regime que

14 Esses são os acontecimentos descritos por PÉREZ, Army politics in Cuba, p. 79-93. Há discordância sobre o fato de os sargentos terem se aproximado de estudantes universitários para construir uma aliança militar-civil, ou se o processo foi inverso.

15 Os novos oficiais nomeados incluíam 363 sargentos, 26 cabos, 32 soldados, 28 oficiais comissionados e 63 civis. PÉREZ. Army politics in Cuba, p. 79-93.

16 Embora o sentido do termo "militares" assuma por vezes uma forma monolítica na história da América Latina, vários excelentes estudos trataram das dissensões entre os conservadores da "direita" e os da "esquerda" (em sua maioria oficiais mais jovens) no seio das forças armadas. Os estudos que alimentaram minha pesquisa foram LOVEMAN, Brian. For la patria: politics and the armed forces in Latin America. Lanham, Md.: Scholarly Resources, 1999; no caso da Argentina, 
sucedia à ditadura dependia largamente do que havia acontecido com a aliança militar-civil. Após 1944, em El Salvador, foi o Exército que governou. Na Guatemala, os militares apoiaram os reformadores civis durante a Revolução de 1944$1954 .{ }^{17} \mathrm{Em}$ Cuba, os líderes militares e civis compartilharam o poder (embora com certo desconforto), de meados de 1933 até 1940, advindo daí a expressão "populismo autoritário".

Mendieta ampliou o alcance político, econômico e jurídico do Estado com sua série de decretos-lei, seus institutos de estabilização do café e do açúcar e seus Tribunais Nacionais de Defesa, mas o cubano médio logo se deu conta do processo de infiltração militar que estava em curso em todos os campos da sociedade. Nas vésperas da colheita de 1935, as autoridades militares provinciais pediram aos proprietários de terra que preparassem uma lista de agitadores e mandaram oficiais do Exército para prendê-los. Durante a colheita, mil soldados foram enviados para as províncias do leste a fim de proteger as usinas e as plantações de cana. Quando as greves começaram a eclodir, o governo mandou soldados e membros da recém-criada "reserva militar" para que atuassem como fura-greves nas usinas, nas empresas de telefonia e de serviços públicos e nas estradas de ferro de toda a Ilha. ${ }^{18}$ Em março de 1935, os seguidores de Grau e de Guiteras convocaram uma greve geral que envolveu 200 mil participantes. Mendieta declarou estado de sítio e suspendeu todas as garantias constitucionais até o fim da colheita. O Exército de Batista e as forças de segurança privadas mataram mais de cem trabalhadores e feriram ou aprisionaram centenas deles. ${ }^{19}$

Foi durante esse estado de sítio que o Exército de Batista usurpou um grande número de cargos preenchidos formalmente por civis. O processo de infiltração

JAMES, Daniel. Resistance and integration, e DEUTSCH, Sandra McGee. The Argentine right: its history and intellectual origins, 1910 to the present. Landham, Md.: Scholarly Resources, 1993; sobre El Salvador, STANLEY, William. The protection racket State: elite politics, military extortion, and civil war in El Salvador. Filadelfia: Temple University Press, 1996; sobre a Guatemala, GLEIJESES, Piero. Shattered hope: the Guatemalan revolution and the United States, 1944-1954. Princeton: Princeton University Press, 1991. p. 16-22; e sobre Cuba, PÉREZ. Army politics in Cuba.

17 Jacobo Arbens, que exerceu a presidência de 1950 a 1954, fez inicialmente parte do Exército, mas renunciou posteriormente a seu posto de ministro da Defesa antes de se candidatar à Presidência da República, trabalhando com partidos políticos civis durante sua permanência nesse cargo. GLEIJESES. Shattered hope, p. 74.

18 PÉREZ. Army politics in Cuba, p. 102-103.

19 Ibid., p. 103-107; DOMÍNGUEZ. Cuba, p. 78; SIMS, “Cuba’s organized labour”, p. 46. 
militar na sociedade já tinha, na verdade, principiado durante os anos finais da ditadura de Machado, quando este enviou oficiais militares a todos os pontos do país para substituir políticos municipais e provinciais eleitos que haviam se agregado à oposição. Após a saída de Machado, as "multidões" assassinaram alguns desses detentores de cargos públicos, e as novas autoridades prenderam outros. Batista preencheu o vácuo resultante nos governos locais com oficiais do Exército, supostamente no aguardo de uma reorganização política e da realização de eleições, o que na verdade transformou o Exército no novo "traficante de influência" da Ilha. ${ }^{20}$ Um cônsul americano em Santiago de Cuba descreveu sem meias palavras a situação na Província de Oriente em 1935:

Os tentáculos do Exército cresceram tanto que chegam agora a controlar até mesmo responsabilidades municipais insignificantes, como a nomeação de garis... Diz-se que essas indicações são distribuídas a parentes próximos e amigos dos soldados e oficiais... De forma vagarosa mas eficiente, os militares estão substituindo os prefeitos de muitos municípios dessa Província. ${ }^{21}$

Esses novos traficantes de influência do Exército logo imitaram o sistema de apadrinhamento e de corrupção que vigorava desde que Cuba se tornara uma nação em 1902. Mas os líderes civis eram eleitos (embora de forma fraudulenta) e, por esse motivo, esperavam algum tempo antes de começarem a roubar. Seus substitutos militares, entretanto, se comportaram como uma máfia. $\mathrm{O}$ adido militar americano E. W. Timberlake tornou explícita essa analogia ao descrever os múltiplos casos de suborno. O coronel Rodrigues, por exemplo, persuadiu os donos de usinas a doar aproximadamente $\$ 35.000$ ao Comando Provincial de Oriente. O coronel José Pedraza conseguia engordar sua conta bancária todos os meses em $\$ 50.000$ com os lucros obtidos com loterias ilícitas. Os guardas rurais, por sua vez, forçavam até mesmo os cubanos mais humildes a dar-lhes seus produtos, seu gado e outras mercadorias agrícolas, sob ameaça de espancamento com a lâmina de suas machetes e outras formas de tormentos. Timberlake concluía dizendo que o chefe do Estado-Maior do Exército era uma espécie de chefe de gangue norte-americana: sempre que assegurasse aos seus tenentes-coronéis

20 PÉREZ. Army politics in Cuba, p. 104.

21 De William P. Blocker para a Embaixada Americana, 29 de novembro de 1935, arquivo (1935) 800, Consulado Americano, Santiago de Cuba, Correspondência diversa, Arquivo Nacional dos Estados Unidos, Grupo de Registro 84, apud Ibid., p. 105. 
ganhos políticos e financeiros e imunidade para seus atos, ele poderia contar com a lealdade e a obediência desse grupo. ${ }^{22}$

Ao fechar os olhos para a corrupção, Batista conseguiu manter a lealdade de um dos pilares do Estado populista autoritário: o Exército. Mas, em contrapartida, o domínio de Mendieta sobre o pilar político - seu ministério - começou a se esfacelar à medida que os ministros passaram a se demitir em protesto contra os excessos do Exército. O próprio Mendieta acabou renunciando, no final do ano 1935. Cuba assemelhava-se cada vez mais a uma ditadura, mas o "ditador" se considerava um revolucionário que havia democratizado a Ilha. Em julho de 1936, Batista defendeu a instauração de "uma democracia renovada na qual impere a disciplina das massas e das instituições, de modo que possamos estabelecer um Estado progressista”. E acrescentou: "Queremos ensinar às massas que o capital e o trabalho são necessários e que todos devem cooperar." ${ }^{23} \mathrm{Um}$ ano depois, ele anunciou: "Muitos querem desconhecer o fato de que sou o chefe de uma revolução social construtiva, e me consideram apenas um cão de guarda da ordem pública. Minha concepção de ordem é mais a de um arquiteto do que a de um policial." ${ }^{4}$

Mas, para que o edifício político de Batista se sustentasse, "as massas" precisavam aderir às instituições. Antes de sua renúncia, Mendieta havia instituído os meios para agregar os trabalhadores por meio da legislação social, e o Exército de Batista, por sua vez, estava pronto para "disciplinar" qualquer um que questionasse suas determinações. Entre a série de decretos presidenciais promulgados sob o disfarce de compromissos entre o capital e o trabalho encontrava-se o Decreto n. 3, de 7 de fevereiro de 1934, que autorizava as greves de trabalhadores, desde que fosse dado um aviso prévio de oito dias. ${ }^{25}$ Essa lei retirava justamente das greves o elemento de espontaneidade que as tornava eficazes. Dava também tempo às empresas para contratar fura-greves e para destituir ou exilar os líderes das greves antes mesmo que elas começassem. Além disso, como o Decreto de

22 Major E. W. Timberlake, adido militar, relatórios G-2 datados de $1^{\circ}$ de dezembro de 1937, 16 de fevereiro de 1938 e 5 de maio de 1938, arquivo 2012-133 (84, 86, 88), Arquivo Nacional dos Estados Unidos, Grupo de Registros 165, apud PÉREZ. Army politics in Cuba, p. 106.

23 PORTER, Russell B. Dual regime denied by Batista. New York Times, p. 1-2, 5 jul. 1936, como citado em WHITNEY. State and revolution in Cuba, p. 133-134.

24 Havana Post, 23 jun. 1937, como citado, Ibid., p. 149.

25 WHITNEY. State and revolution in Cuba, p. 125. 
Defesa Nacional proibia qualquer "reunião política não autorizada”, essas medidas dificultavam ao máximo as reuniões legais de trabalhadores.

Os líderes trabalhistas se deram logo conta da natureza controladora das assim chamadas "reformas".

Os comunistas, os trotskistas e aqueles que apoiavam os depostos Grau e Guiteras rejeitaram imediatamente o pacto populista. Um manifesto da Confederación Nacional Obrera de Cuba (CNOC) declarou:

Nossos conflitos têm de ser resolvidos através de ação direta com os patrões, sem intermediários de qualquer natureza. Não devemos de forma alguma notificar o Ministério do Trabalho. Nossa atitude deverá ser a mesma adotada com relação a Grau e ao Ministério do Trabalho. Não reconhecer, e boicotar totalmente. ${ }^{26}$

Os trabalhadores das usinas Chaparra e Delicias e os do porto de Juan Claro seguiram esse conselho e resolveram rejeitar o Decreto $\mathrm{n}^{\circ} 3$ em sua reunião realizada no domingo, dia 11 de fevereiro de 1934. O sindicato enviou suas reivindicações somente aos patrões, o que não é de surpreender, já que a saída de Grau e de Guiteras significava o fim da "intervenção" estatal na Cubanaco. Os trabalhadores optaram por negociar com os patrões como sempre haviam feito; a intervenção do Estado - ou o populismo - permaneceu uma promessa passageira. Se examinarmos as reivindicações do contrato coletivo de trabalho que os trabalhadores haviam redigido naquela época, poderemos ter uma ideia do que o pacto populista teria de fazer se quisesse conseguir o apoio dos trabalhadores. Os residentes das usinas de açúcar e os residentes das fazendas de cana queriam formalizar e melhorar muitos benefícios que os patrões da era da Depressão consideravam dispensáveis, inclusive alojamento durante o ano inteiro, escolas, transporte, aposentadorias, tratamento médico e indenizações por acidente. Os sindicatos dos portuários, dos ferroviários e dos trabalhadores na indústria da cana queriam maior controle do recrutamento e das promoções. Essas reivindicações começaram com a exigência de reconhecimento dos sindicatos por parte da empresa e da concessão de locais. Outra exigência consistia na readmissão de todos os trabalhadores que haviam sido demitidos entre 1925 e 1934 por motivo de ativismo trabalhista (surpreendentemente, essa exigência foi efetivamente

26 "Circular sobre la lucha contra decreto ley de prohibición de huelgas", [s.d.], Instituto de História, Sindicato Nacional de Obreros en la Industria Azucarera, [hereafter IH, SNOIA], 1/8:87/6.1/13-18. 
atendida quando o populismo se aprofundou no fim da década de 1930). Pela Reivindicação $\mathrm{n}^{\circ} 14$, nenhum empregado poderia ser demitido até que o sindicato correspondente da usina de açúcar ou da fazenda de cana aprovasse o "registro de seu caso". A Reivindicação no 34 pedia a rigorosa observância dos direitos de antiguidade, e qualquer exceção deveria ser aprovada por um júri que incluísse representantes sindicais. Várias outras reivindicações buscavam condições de "closed shop" (sistema fechado) - hierarquia de cargos na qual somente os membros do sindicato podiam ser promovidos de acordo com seu tempo de serviço.

Todas essas reivindicações representavam um esforço para combater o favoritismo e o racismo que fomentavam a divisão entre os trabalhadores. Os sindicatos, na verdade, combatiam diretamente o racismo por meio de três reivindicações "específicas para os cubanos de cor": salário igual para trabalho igual, o fim da segregação racial na concessão de moradia e empregos e o direito de ocupar qualquer cargo nas usinas de açúcar e em seus escritórios. Os trabalhadores cubanos conseguiram obter maior controle sobre as contratações e demissões durante o período que vai de 1934 a $1959 .{ }^{27}$ As barreiras racistas eram extremamente tenazes.

Três reivindicações parecem revelar o que os trabalhadores consideravam o papel adequado das mulheres e das famílias. Uma delas pedia a criação de um local de trabalho nas usinas, onde os tecidos de filtragem pudessem ser reparados e os sacos de açúcar, confeccionados. Esse trabalho deveria ser feito "exclusivamente por mulheres". Não ficou bem claro como eram realizadas essas tarefas antes de 1934. É possível que os homens não quisessem mais executar o que consideravam ser um "trabalho de mulher", ou então os cubanos queriam que suas mulheres e filhas consertassem produtos que eram anteriormente fabricados ou consertados nos Estados Unidos. Seja qual for a razão, isso constitui uma prova de que os trabalhadores do sexo masculino queriam que as mulheres comple-

27 Emprego a expressão trabalhadores "cubanos" porque muitos trabalhadores estrangeiros acabaram perdendo seus empregos quando o governo passou a aplicar a lei dos $50 \%$ de forma mais estrita em fins de 1930. Os trabalhadores cubanos conseguiram obter elevado nível de segurança na manutenção de seus empregos, e isso a tal ponto que a empresa tinha de oferecer dinheiro àqueles que ela pretendia excluir para extinguir determinados cargos, tendo em vista que a legislação do país tornava quase impossível a extinção de funções nas usinas de açúcar. 
mentassem a renda familiar. Outras reivindicações destinavam-se a formalizar apoio para a contratação de parteiras. ${ }^{28}$

E, finalmente, a reivindicação mais significativa (nunca totalmente conseguida) obrigava a empresa a fornecer lotes de terra, sem qualquer contrapartida de aluguel, para todos os trabalhadores e empregados da usina, das áreas de plantação e dos escritórios. Estava subentendido que as mulheres e crianças iriam cuidar da criação de gado ou da produção agrícola nessas terras, exceto durante os períodos de entressafra, quando os trabalhadores do sexo masculino dispunham de tempo livre. $\mathrm{O}$ excedente de alimentos ou a renda suplementar que as mulheres e crianças auferiam lavando roupa, criando porcos ou colhendo bananas constituíam uma proteção essencial contra o desemprego durante as entressafras prolongadas e contra os baixos rendimentos da força de trabalho predominantemente masculina nas usinas de açúcar. ${ }^{29}$

Os trabalhadores tinham esperanças de reconstruir seu relacionamento com os patrões de forma mais sólida - e em bases mais igualitárias. Os patrões se mostravam intransigentes, presumindo que Mendieta e Batista iriam comportar-se da mesma forma que os presidentes anteriores, derramando retóricas populistas para ganhar as eleições, mas passando depois à repressão para garantir a colheita.

Batista não os desapontou. A expressão habrá zafra o habrá sangre (haverá safra ou haverá sangue) começou a ecoar à medida que os soldados de Batista invadiam as sedes de sindicatos em toda a Ilha. No dia 15 de fevereiro de 1934, os trabalhadores das usinas de Chaparra e de Delicias encontraram suas instalações fechadas e suas portas e janelas pregadas. O senhor R. B. Wood, da Cubanaco, aconselhou seus superiores a não fazer qualquer oferta e até mesmo a não negociar com os líderes da greve de 1934, já que eles continuavam a desacatar a nova

28 As duas reivindicações concernentes às parteiras eram assim redigidas: "Chaparra, Delicias, Vazquez e Cayo Juan Claro [deverão ter] parteiras pagas pela empresa e pelos fazendeiros de cana" e "as parteiras deverão ser munidas do equipamento e dos materiais exigidos por sua profissão".

29 Sindicato Nacional dos Trabalhadores da Indústria Açucareira, Seção Sindical de Chaparra Oriente, "Bases a Serem Apresentadas à Cuban-American Sugar Company, Proprietária das Centrais Chaparra e Delicias, pelos vários Sindicatos desta Região", Anexo no 4, despacho 512, 13 fev. 1934, Embaixada de Havana, Arquivo Nacional dos Estados Unidos, Grupo de Registro 59 [daqui por diante, USNA, RG], prateleira 250, fileira 26, arquivo decimal 1900-1939, caixa 1339, 337.115 SM/665-337.1153-CU. 
legislação de Mendieta. ${ }^{30}$ Wood mencionou ter ouvido rumores de que os trabalhadores iriam cometer atos de sabotagem em retaliação contra a repressão, mas dizia não levar fé nesses rumores. Foi um grande erro. Os registros da Cubanaco sobre segurança mostram que, na verdade, os atos de sabotagem e de roubos aumentaram significativamente durante o período de 1934 a 1938, quando os trabalhadores foram privados de um sindicato legítimo. ${ }^{31}$

Com a desculpa de fazer cumprir o Decreto de Defesa Nacional, os soldados de Batista esmagaram até mesmo os sindicatos de pequenas usinas, como a de Manuel Rionda, em Tuinucú. Os soldados destruíram todos os documentos e toda a mobília, prenderam ou destituíram os líderes trabalhistas da usina e declararam seus sindicatos ilegais.

A despeito de todas as promessas populistas em contrário, o Estado colocou todo o seu suporte a serviço dos donos de usinas e nenhum aos trabalhadores. A correspondência da empresa revela que os donos das usinas usaram seus advogados e ofereceram generosas propinas a seus "amigos" para assegurar que as medidas sociais fossem diluídas e postergadas. A tática mais comum consistia em não comparecer às reuniões com os representantes do Ministério do Trabalho - ou subornar os representantes do ministério para que não comparecessem - e então declarar as petições dos empregados inválidas, já que não havia qualquer representação da empresa ou do ministério. Ou então os administradores enviavam um representante às reuniões, mas declaravam que este não estava autorizado a tomar qualquer decisão. Em 1939, a Cubanaco conseguiu uma verdadeira reviravolta quando um grupo de trabalhadores "amigos" constituiu um sindicato "legal" no porto de Juan Carlos para substituir o sindicato existente, evitando, assim, o substancial contrato de trabalho conseguido em 1934.

Os produtores de cana se encontravam em posição bem mais confortável do que os trabalhadores. Como grande parte deles era de cubanos da classe média e alta, obtiveram o apoio dos corredores do poder em Havana. Alguns tinham até assento na Câmara dos Deputados de Cuba. Os governos de meados da década

30 Memorando do dia 15 de fevereiro sobre a conversa telefônica entre R. B. Wood e Joseph B. Harris, representante da Cubanaco em Havana, apresentado por H. Freeman Matthews, encarregado de negócios ad interim do secretário de Estado USNA, RG 59, prateleira 250, fileira 26, arquivo decimal 1900-1939, caixa 1339, 337.115 SM/665-337.1153-CU.

31 Essa conclusão baseia-se em uma comparação dos arquivos Jurado no Archivo Provincial de Las Tunas, arquivos da Cuban American Sugar Company [daqui por diante, APLT, CASC]. 
de 1930 promulgaram uma série de decretos para salvar os produtores de cana-de-açúcar, reforçando algumas medidas que Grau já havia introduzido (como o direito dos fazendeiros arrendatários de permanecer nas terras que cultivavam), além de acrescentar outras (como a moratória de 17 de agosto de 1934 para ajudar os plantadores de cana a pagar suas dívidas). Uma nova lei estabeleceu quotas de produção para os fazendeiros produtores de cana e reforçou o controle do Estado por meio do Instituto Cubano de Estabilização do Açúcar (Icae), do qual faziam parte seis representantes dos fazendeiros, juntamente com 13 representantes das usinas, além de um delegado presidencial. A legislação do Estado protegia os produtores de cana contra a reintegração da posse da terra, e as quotas de produção garantiam-lhes mercado para sua produção. Contudo, muitos produtores de cana consideravam que suas quotas eram pequenas demais para garantir seu sustento.

Os trabalhadores do campo apoiavam com frequência as greves dos trabalhadores das usinas, mas de maneira geral eles demoravam mais a se organizar e faziam reivindicações em separado por diversas razões. Uma delas era o fato de que eles estavam espalhados pelas diversas fazendas de cana e viviam muitas vezes isolados em cabanas de sapê (por outro lado, os trabalhadores das usinas viviam em espaços urbanos concentrados, e muitas de suas casas, até mesmo as mais humildes, tinham varandas com balanços ou cadeiras nas quais podiam trocar experiências e organizar movimentos de protesto).

\section{O pacto se aprofunda: a coordenação do açúcar e a frente popular, 1937-1944}

O populismo permitiu que as comunidades das usinas obtivessem vantagens significativas por parte dos donos das usinas. A Lei de Coordenação do Açúcar, de 1937, estabeleceu um novo sistema permanente de divisão dos lucros entre os trabalhadores, os produtores de cana e os donos das usinas de açúcar, funcionando de acordo com uma escala móvel que se deslocava de acordo com o preço do açúcar. Descrita por um analista como "a peça-mestra da legislação" - e, em consequência, a pedra fundamental do sistema político até 1959 -, essa legislação era fundamentalmente populista, pelo fato de garantir a redistribuição da renda 
entre as classes sociais. ${ }^{32}$ Por outro lado, oferecia tanta proteção nacionalista às usinas e aos produtores de cana cubanos que foi possível "cubanizar" grande parte da produção de açúcar antes da Revolução de 1959. Em fins de 1959, a cana proveniente de plantações pertencentes às usinas praticamente desapareceu, e os plantadores de cana produziam oficialmente $94 \%$ da cana para as usinas de Cuba. ${ }^{33}$ Os cubanos também detinham naquele momento quase $70 \%$ da indústria açucareira, em comparação com os cerca de $30 \%$ em $1925 .{ }^{34}$

Os políticos americanos não davam ouvidos aos inevitáveis protestos do grupo Rionda, Cubanaco e de outras empresas americanas contra a Lei de Coordenação. O defensores do New Deal do presidente Roosevelt priorizavam a estabilidade política e econômica dos cubanos - e, portanto, sua capacidade de consumir mais produtos americanos - em detrimento dos lucros de alguns magnatas americanos do açúcar. ${ }^{35} \mathrm{O}$ pacto populista prejudicou proprietários individuais americanos de usinas de açúcar, mas, em última análise, os políticos americanos ainda mantinham nas mãos as rédeas da economia cubana. Em 1934, Cuba assinou um novo tratado de reciprocidade, que concedia aos Estados Unidos tarifas reduzidas em um total de 406 categorias de mercadorias, em comparação com as 251 categorias preferenciais de 1902. Esses produtos americanos ganharam maiores reduções tarifárias (25-60\% de preferência garantida contra 20-40\% em 1902) Em contrapartida, foi dada a Cuba uma parte do mercado americano para o açúcar, o rum e o fumo menor do que a de 1902. O novo tratado havia revertido o processo de diversificação que começara a beneficiar os cubanos com as tarifas de Machado em 1927. ${ }^{36}$

A principal razão da concordância das elites cubanas com o novo tratado de reciprocidade e com a Lei Jones-Costigan sobre o açúcar é que continuavam a

32 Ibid.; DOMÍNGUEZ. Cuba, p. 85.

33 A palavra "oficialmente" é aqui empregada porque, às vezes, as empresas mascaravam os dados reais da cana própria, inventando a existência de plantações no papel; alguns desses casos ocorreram em Tuinucú e Chaparra. MARTINEZ-ALIER, Juan; MARTINEZ-ALIER, Verena. Cuba. economia y sociedad. Paris: Ruedo Ibérico, 1972. p. 81.

34 Ibid., p. 63.

35 HOERNEL, Robert. A comparison of sugar and social Change in Puerto Rico and Oriente, Cuba: 1898-1959. Dissertação (Ph.D.) - Johns Hopkins University, 1977. p. 168.

36 FARBER The origins of the Cuban revolution reconsidered. Chapel Hill: University of North Carolina Press, 2006. p. 11. 
acreditar que o açúcar ainda era sua melhor alternativa e queriam desesperadamente um mercado seguro para esse produto. A Lei de Coordenação do Açúcar, de 1937, dividiu a quota total de açúcar entre as usinas ${ }^{37}$ e especificou que a usina deveria moer pelo menos 30 mil arrobas de cana por ano de cada um de seus produtores (a moagem da cana própria - administration cane - só seria feita se restasse uma quota extra). Essa lei fez com que as usinas de açúcar pagassem pelo menos 5,5 arrobas de açúcar para cem arrobas de cana aos produtores de cana proprietários de terras, e cinco arrobas para os arrendatários. Ela também dava o "direito de ocupação permanente" aos arrendatários de terra, fixando o arrendamento em índices bastante baixos. Por último, mas não menos importante, a lei especificava que os salários dos trabalhadores da indústria do açúcar deveriam subir e baixar de acordo com o preço médio do açúcar. As empresas e os produtores de cana seguiram essa norma até 1947, quando os preços do açúcar, após a Segunda Guerra Mundial, subiram de tal modo que os empregadores recusaram-se a dar aos trabalhadores o pagamento correspondente. Essa medida deslanchou uma onda maciça de greves. Mas a atmosfera da Guerra Fria tornava difícil que os trabalhadores reivindicassem o que lhes era devido.

Fatores internacionais ajudam a explicar por que o clima social se mostrava muito mais favorável aos trabalhadores em 1937. O pacto populista tornava-se mais forte à medida que Batista adotava uma posição mais à esquerda, e os líderes dos trabalhadores pendiam para o centro. À Lei de Coordenação do Açúcar, de 1937, seguiram-se uma anistia geral para os prisioneiros políticos, um Código Trabalhista bastante progressista em 1938 e uma decisão da Suprema Corte, naquele mesmo ano, estabelecendo que "as relações trabalhistas não constituíam uma questão privada”. A decisão obrigava os proprietários a fornecer ao Estado informações sobre os salários e a produção, para que ele pudesse atuar como mediador entre patrões e empregados, em uma autêntica fórmula populista.

Três fatores básicos contribuíram para a guinada de Batista em direção à esquerda. Os comunistas, os anarcossindicalistas e os Auténticos (que apoiavam Grau San Martin) criaram uma frente popular, organizando grandes passeatas e lançando uma campanha internacional destinada a obter anistia para todos os presos políticos e a angariar fundos para a luta contra o regime fascista de Fran-

37 A quota estabelecida pelos Estados Unidos permitia calcular uma estimativa da quantidade de açúcar a ser vendida no próprio país e nos mercados fora dos Estados Unidos. 
cisco Franco na Espanha. Batista foi conhecer o regime de Cárdenas, no México, lá encontrando um modelo de democracia populista que ele pretendia copiar - e que os próprios trabalhadores também queriam seguir. Por fim, a aliança entre Estados Unidos e Rússia contra o fascismo na Europa, durante a Segunda Guerra Mundial, pressionou participantes da política de boa vizinhança a não se aproximarem tanto dos comunistas e a se afastarem de qualquer tendência fascista dentro do país. ${ }^{38}$ A confluência dessa pressão pela democracia e de uma união contra o fascismo acabou criando um "momento populista" com duração suficiente para que os trabalhadores cubanos conquistassem reformas ainda mais profundas no período entre 1937 e 1947. A situação econômica do início até meados dos anos 1940 também era propícia para a economia cubana, já que a Segunda Guerra Mundial refreara a produção do açúcar de beterraba na Europa, aumentando a demanda por açúcar no mercado mundial e fazendo literalmente com que os líderes populistas tivessem algo mais a distribuir.

Fatores internos também contribuíram para essa virada. Grau San Martín, que vivia exilado em Miami, constituía uma alternativa bastante popular a Batista. Destituído antes que tivesse a oportunidade de voltar-se contra os trabalhadores ou participasse da corrupção vigente, Grau era lembrado por seus decretos populares de 1933. O populista Batista tentou aliar-se a Grau, como também fizeram os comunistas, mas este repeliu a aproximação de ambos, lançando-os uns contra os outros. Os primeiros presidentes de Cuba haviam buscado uma base de poder junto aos proprietários das usinas. Machado e Grau acrescentaram os industriais e os produtores de cana a essa combinação. Em 1938, Batista afastou-se um pouco mais de sua base armada de poder, trazendo os trabalhadores para junto do Estado. Legalizou o Partido Comunista e permitiu que ele fundasse um jornal e uma emissora de rádio, na esperança de que os comunistas pudessem organizar "as massas" em torno de seu novo "salvador" democrático. Abandonou oficialmente o posto de comandante das forças armadas e iniciou sua campanha para as eleições presidenciais de 1940.

Os líderes comunistas iniciaram seus planos para uma nova união nacional (em substituição ao CNOC, que o próprio Batista havia dissolvido após a greve

38 Essas tendências "fascistas" incluíam a eliminação da oposição pela força, um nacionalismo beligerante, racismo e militarismo. Os fatores internacionais e domésticos citados anterior e posteriormente foram pesquisados em várias fontes, como WHITNEY. State and revolution in Cuba; ZANETTI, "The workers' movement and labor regulation in the Cuban sugar industry", p. 193. 
de março de 1935), por ocasião do primeiro Congresso dos Trabalhadores da América Latina (CTAL) realizado no México em 1938. O local escolhido para a reunião comprova que a decisão dos líderes trabalhistas cubanos de aliarem-se ao recém- "democrata” Batista não havia sido tomada no vácuo. O Comintern soviético havia influenciado esses líderes - defendendo uma frente popular de socialistas, comunistas e partidos de classe média contra o fascismo -, mas as profundas transições populistas que ocorriam perto dali, no México, também exerceram sua influência. ${ }^{39}$

A lembrança do sectarismo que dividira o movimento trabalhista durante a Revolução de 1933 também deve ter pesado consideravelmente na decisão dos líderes comunistas de se aliarem a outras facções políticas em 1939. Os membros da Federación Obrera de la Habana (FOH), trotskista, e o CNOC comunista, antes tão antagônicos, uniram-se sob a competente liderança de um trabalhador afro-cubano da área do tabaco, chamado Lázaro Peña. Tratava-se de um comunista dotado de forte tino político e da capacidade de negociar com líderes de outros movimentos. ${ }^{40}$ Essa abertura foi benéfica para a organização: em fins de 1939, a nova Confederação dos Trabalhadores Cubanos (CTC) contava com mais de 200 mil adeptos. Dois anos depois, já eram quase 350 mil. ${ }^{41}$ Cerca de três quartos dos trabalhadores sindicalizados pertenciam à Central de Trabalhadores de Cuba (CTC). O restante pertencia a sindicatos independentes ou à Comissão Nacional dos Trabalhadores, de Grau, sob o comando de Eusébio Mujal. Em 1942, Mujal procurou forçar uma cisão na CTC, mas recuou ao perceber que os trabalhadores acreditavam na necessidade de uma união trabalhista contra o fascismo. ${ }^{42}$

Os trabalhadores perceberam as grandes vantagens que uma "classe trabalhadora" unida e autodefinida poderia colher com presidentes populistas e uma economia de guerra em plena expansão baseada no açúcar. Os produtores de

39 O Comintern era uma organização comunista internacional fundada em Moscou, que orientava os membros do Partido Comunista no exterior, de 1919 a 1935. Para mais informações sobre o comunismo em Cuba, ver CARR. From Caribbean backwater to revolutionary opportunity. In: REES, Tim; THORPE, Andrew (Eds.). International Communism and Communist International, 1919-1943. Manchester: Manchester University Press, 1998. p. 234-253.

40 SPALDING JR., Hobart. Organized labor in Latin America: historical case studies of workers in dependent societies. Nova York: New York University Press, 1977. p. 228.

41 Ibid., p. 228.

42 Ibid., p. 230. 
cana já se haviam organizado anteriormente como classe para exigir reivindicações de Machado, Grau e Mendieta, e continuaram essas ações (com sucesso) com Batista e os Auténticos. Ao permitir a expansão da CTC e oferecer amplas concessões aos trabalhadores em troca de apoio político, Batista foi o primeiro presidente a efetivamente autorizar que os trabalhadores participassem da política cubana. Os empresários acreditavam que se tratava apenas de uma passageira fase populista, como as que Cuba havia experimentado em 1924 e 1933. Mas estavam enganados. Essa fase populista estendeu-se por duas administrações, e a reação só surgiu ao final do segundo regime de Grau, em 1947. Sua tática de retardar o processo funcionou de fato na escolha do momento apropriado para a agricultura. Como Wood previra, não ocorreu qualquer nova audiência de negociação até abril, quando a colheita estava praticamente concluída e a Cubanaco adotara "medidas para garantir o funcionamento eficiente durante a entressafra" - em outras palavras, os desordeiros foram demitidos e os trabalhadores excedentes foram dispensados. O retardamento das negociações na verdade fez com que o aumento só se aplicasse à colheita seguinte. ${ }^{43}$

Os líderes da CTC rapidamente perceberam como utilizar o espaço criado pela política interna e internacional a fim de impedir esse tipo de trapaça. Em março de 1935, os trabalhadores não tiveram outra escolha senão modificar sua posição após a repressão que se seguiu ao fracasso da greve geral (e ao assassinato de Guiteras, três meses depois). Os líderes comunistas pouco a pouco começaram a advogar um trabalho no próprio interior do sistema para evitar uma violência maior. A partir do final de 1935, os sindicatos localizados em Havana distribuíram circulares aos trabalhadores das usinas de açúcar da Ilha, explicando como legalizar os sindicatos, e os ensinaram a combater de maneira mais eficaz as táticas que empresas como a Cubanaco estavam adotando para contornar a legislação. Ursinio Rojas, preso em 1935 por suas atividades de articulação na usina de Tacajó, aprendeu várias dessas táticas na cadeia, onde teve contato com líderes e trabalhadores comunistas de Cuba. Ele descreveu as prisões como "universidades para revolucionários", onde o Manifesto comunista era lido em voz alta e os prisioneiros aprendiam os benefícios de se manterem unidos, formando cooperativas para dividir as doações. As famílias dos prisioneiros reuniam itens como remédios, sabonetes, pastas de dentes e livros, por meio de novas organi-

43 Ibid. 
zações de frente popular "antifascistas e pró-anistia política", como a Federação Democrática das Mulheres Cubanas (FDMC). ${ }^{44}$

Os líderes cubanos decidiram agir para aprimorar da melhor forma possível a legislação vigente, que era favorável apenas superficialmente aos trabalhadores, combatendo-a, dessa vez, a partir do interior das organizações. Para isso, consideraram mais acertado juntar-se aos sindicatos ratificados pelo governo, tornando-os mais poderosos, e assumir pouco a pouco a liderança dos sindicatos anteriormente "amarelos". A decisão dos trabalhadores de combater a nova legislação foi o que acabou tornando Cuba "populista" nessa era. Com efeito, diversos líderes desde a época de Menocal haviam tentado organizar falsos congressos trabalhistas, que, no entanto, não haviam conseguido um número de participantes suficiente para legitimá-los. ${ }^{45}$

Os trabalhadores do setor açucareiro, em especial, obtiveram expressivos progressos em termos de salários e benefícios no período entre 1939 e 1947, sob a nova Federação Nacional dos Trabalhadores da Atividade Açucareira (FNOA) - rebatizada de Federação Nacional dos Trabalhadores da Indústria Açucareira (FNTA) em 1945 -, que incluía desde os trabalhadores das camadas mais baixas da categoria (trabalhadores do campo nas plantações de cana-de-açúcar) até funcionários de alto escalão (inicialmente sindicalizados em separado, na Associação Nacional dos Funcionários dos Escritórios da Atividade Açucareira e na Associação Nacional dos Técnicos da Atividade Açucareira). ${ }^{46} \mathrm{O}$ congresso de agosto de 1945 reuniu 200 sindicatos, representando cerca de 480 mil trabalhadores. ${ }^{47} \mathrm{~A}$ agora unificada "classe dos trabalhadores nas atividades açucareiras" conseguiu pressionar os presidentes populistas, alinhando-se com sua contra-

44 ROJAS, Ursinio. Las luchas obreras en el central Tacajó. Havana: Política, 1979. p. 96.

45 Em muitos dos estudos iniciais sobre populismo em outras partes da América Latina, os acadêmicos marxistas condenavam os trabalhadores por não estarem imbuídos de suficiente "consciência de classe" para rejeitar a liderança populista. Eles argumentavam que os líderes populistas, como Juan Perón e Getúlio Vargas, enganavam os trabalhadores apresentando-se como pais dos pobres, salvadores dos trabalhadores etc. O estudo pioneiro de Daniel James sobre Perón apresenta o argumento muito menos crítico (e mais convincente) de que os trabalhadores preferiam os populistas porque estes ofereciam a melhor alternativa à violenta repressão dos regimes mais conservadores anteriores. Ver JAMES. Introdução. In: Resistance and integration.

46 VILLAFRUELA, Omar. El general de las cañas. Las Tunas: Sanlope, 1999. p. 14.

47 SIMS, Harold D. The Cuban sugar workers' progress under the leadership of a black communist, Jesús Menéndez Larrondo, 1941-1948. Maclas Latin American Essays, n. 6, p. 11, 1993. 
parte da "classe dos plantadores de cana-de-açúcar". Um relatório de 1947 de R. B. Wood, da Cubanaco, observou que, "durante os últimos cinco ou seis anos, por conta de decretos presidenciais, as empresas açucareiras tiveram de aumentar em mais de $200 \%$ os salários de seus trabalhadores e funcionários, a partir do salário-base de 1940".48 O Decreto no 100 de Batista aumentara os salários em 50\% em 1942, e em 1943 ele estendeu o "direito à estabilidade no emprego" aos trabalhadores do setor açucareiro. Isso fez com que os proprietários das usinas de açúcar acabassem desistindo de demitir seus trabalhadores com a finalidade de promover uma contenção de custos trabalhistas.

Grau San Martin estava ansioso para conquistar o apoio dos trabalhadores após vencer a corrida presidencial em 1944, muito especialmente porque os líderes comunistas da CTC ameaçavam convocar uma greve geral caso ele os substituísse pelos Auténticos. Os comunistas lideravam um terço de todos os trabalhadores sindicalizados e um número ainda maior de trabalhadores do setor açucareiro, de modo que o distanciamento desses trabalhadores poderia ensejar um tipo de greve que daria a Batista o pretexto para executar um golpe militar contra ele. Os Auténticos do novo presidente e os comunistas chegaram a uma solução de compromisso. Lázaro Peña permaneceria como secretário-geral, e os demais cargos do Comitê Executivo seriam distribuídos por igual. ${ }^{49}$ Para garantir apoio, Grau concedeu aos trabalhadores do setor açucareiro um aumento salarial de $32 \%$ para a colheita de $1945 .{ }^{50} \mathrm{O}$ salário médio dos trabalhadores nas usinas de açúcar mais que duplicou entre 1940 e 1945, chegando a quase $\$ 2$ por dia. ${ }^{51}$ Durante a década de 1940, o Executivo continuou a conceder aumentos salariais,

48 R. B. Wood à Companía General de Seguros y Fianzas de Sagua la Grande, S.A., 12 fev. 1947, APLT, CASC, leg. 71, exp. 811.

49 SPALDING. Organized labor in Latin America, p. 230.

50 SIMS. “Cuba’s organized labor", p. 48.

51 O índice para os trabalhadores nas usinas aumentou de 96,4 centavos em 1940 para 198,5 centavos em 1945; para os trabalhadores no campo, subiu de 70,7 centavos em 1940 para 180,4 centavos em 1945. IH, Fondo: Museo Obrero, leg. Organizaciones de Trabajadores Azucareros, 19241975, Fichero no 8, 8/E15/G4/C1/12; Colectivo de autores. Memorias de un viejo mundo azucarero. Havana: Editorial de Ciencias Sociales, 1990; ZANETTI. “The workers' movement and labor regulation in the Cuban sugar industry", p. 183-205. 
e os tribunais trabalhistas decidiam em favor dos trabalhadores a cada três de cinco casos de demissão. ${ }^{52}$

Voltando a 1939, as mobilizações populares internas, a pressão diplomática e a vontade de conquistar a presidência de forma democrática haviam levado Batista a convocar uma Convenção Constitucional. A decorrente Constituição de 1940 era, talvez, a mais progressista da América Latina, pelo menos no papel. Os comunistas desempenharam uma função fundamental na convenção, redigindo os 27 artigos referentes às questões trabalhistas. Entre outros benefícios, a Constituição concedia "estabilidade" aos empregados após seis meses de trabalho, promovia aumentos salariais em atividades urbanas, concedia benefícios de previdência social a partes da classe trabalhadora e reconhecia o direito de organização. Em suma, estabelecia o Estado de bem-estar em Cuba. ${ }^{53}$

Hugh Thomas e Robert Hoernel, entre outros, frisaram que os triunfos do movimento trabalhista se refletiram na Constituição de 1940, e as leis que vieram a seguir foram extremamente desigualitárias. Eles argumentaram, em especial, que os trabalhadores rurais não se beneficiaram de muitos desses avanços. ${ }^{54}$ Foi, sem dúvida, o caso dos trabalhadores rurais da área cafeeira e algumas vezes dos trabalhadores rurais do setor açucareiro. Mas os trabalhadores rurais das usinas de açúcar acabaram conquistando muitos benefícios quando homens como Jesús Menéndez e Melanio Hernández os ajudaram a se organizar e fazer reivindicações. Esses homens, da mesma forma como Enrique Varona, antes deles, vislumbraram a importância de ultrapassar a linha divisória ocupacional (e muitas vezes racial) entre a fábrica e o campo. É importante observar que Jesús Menéndez e Melanio Hernández foram ambos cortadores de cana - e, posteriormente, trabalhadores nas usinas - antes de começarem a se organizar e conquistar importantes reivindicações em favor dos trabalhadores da área açucareira. Vale também notar que ambos eram afro-cubanos (é bom lembrar que os trabalhadores nas usinas tinham geralmente a pele mais clara do que os trabalhadores rurais, e que as reivindicações dos sindicatos incluíam a instituição do direito dos

52 STABLE, Marifeli Pérez. The Cuban revolution: origins, course, and legacy. 2. ed. Nova York: Oxford University Press, 1993. p. 44.

53 SIMS. "Cuba's organized labour", p. 47.

54 HOERNEL. "A comparison of sugar and social change in Puerto Rico and Oriente", p. 203-208; THOMAS, Hugh. Cuba, the pursuit of freedom. Nova York: Harper and Row, 1971. p. 1.122. 
mulatos e negros a galgar os degraus da profissão, livres de discriminação). Como muitos afro-cubanos juntaram-se a Menéndez e Hernández nas hostes do trabalho organizado, estes tiveram condições de lutar melhor contra as desigualdades - embora longe de abrangê-las integralmente - relativas ao emprego e ao salário entre brancos e negros, que imperavam em todas as demais partes do hemisfério. ${ }^{55}$

Nascido em uma região de plantações de tabaco em Santa Clara em 1911, neto de uma escrava e filho de veteranos do Exército da Libertação, Jesús Menéndez começou a trabalhar em uma plantação de tabaco aos 13 anos. Havia cursado apenas quatro anos da escola primária. Começou a cortar cana com 14 anos e conseguiu um emprego na "casa de purgar" da usina de açúcar Constancia; filiou-se ao Partido Comunista aos 20 e fundou o primeiro sindicato das usinas de açúcar. Foi preso em 1932 por organizar uma marcha da fome com mais de 3 mil pessoas em Las Villas e solto em 1933. Escapou por pouco de uma tentativa de assassinato após a greve de março de 1935, e ressurgiu em 1936 para liderar um novo sindicato do setor açucareiro em Constancia. Os soldados saquearam as instalações do sindicato e prenderam Menéndez. Ao ser libertado, dedicou-se à organização de uma federação de trabalhadores provinciais que congregava trabalhadores dos setores de açúcar e tabaco. Deixou o cargo de secretário-geral da nova Federação de Trabalhadores Provinciais de Santa Clara (fundada em 1938) ao ser eleito para o comitê executivo da CTC em 1939. Participou do Congresso Constitucional de 1939 e ajudou a organizar a primeira Federação Nacional dos Trabalhadores do Setor Açucareiro naquele mesmo ano. Atuou simultaneamente como líder da FNOA (posteriormente FNTA) e como deputado comunista na Câmara dos Deputados de 1940 até sua morte, aos 36 anos, em $1948 .{ }^{56}$ Menéndez visitava Tuinucú e Chaparra com frequência, e essas visitas às usinas de açúcar da Ilha deram origem a muitas das reivindicações que ele fazia em âmbito nacional por meio das federações açucareiras. ${ }^{57}$

55 Para detalhes sobre raça e mercado de trabalho, ver FUENTE, Alejandro de la. A nation for all: race, inequality, and politics in twentieth century Cuba. Chapel Hill: University of North Carolina Press, 2001. p. 99-137; PÉREZ. Cuba, p. 306-307.

56 SIMS. “The Cuban sugar workers' progress under the leadership of a black communist”, p. 10; VILLAFRUELA. El general de las cañas, p. 7-21.

57 E ele também ajudou os trabalhadores a fazerem reivindicações locais específicas. Por exemplo, durante uma visita a Chaparra, em 1942, Menéndez testemunhou as condições desumanas das 
Uma das mais importantes metas da FNOA foi atingida, ao menos brevemente, durante os anos que se seguiram à guerra em 1945-1947. Foi quando os trabalhadores conquistaram o diferencial azucarero. A Lei de Coordenação do Setor Açucareiro estipulava que, ao final de cada ano, os plantadores de cana recebessem a diferença entre o preço médio do açúcar durante a colheita e o preço médio referente ao ano inteiro. Sob a liderança de Menéndez, os trabalhadores exigiram que esse diferencial fosse estendido aos trabalhadores. A famosa convocação dos trabalhadores açucareiros que se fez ouvir dos anos 1940 até 1959 os conclamava a "exigir o diferencial com a ponta dos seus machetes!" 58

Menéndez também reivindicava outro diferencial, este dos Estados Unidos - a diferença entre os custos crescentes das importações dos Estados Unidos (devido à inflação do pós-guerra) e os custos do açúcar cubano que era vendido àquele país (fixado pelo acordo de reciprocidade). Em outubro de 1945, Menéndez viajou para Washington, D.C., com o bem considerado contador da FNTA Jacinto Torres, para abrir o caminho das negociações sobre a cota do açúcar de Cuba. Delegações de plantadores de cana, usineiros e diplomatas cubanos e americanos estiveram presentes à reunião, juntamente com a Commodity Credit Corporation dos Estados Unidos, que comprava o açúcar. Menéndez sofreu discriminação racial em Miami, no trem, e em Washington, mas ele e Torres conseguiram vencer todos esses obstáculos e relatar os fatos econômicos aos americanos. Mas os cubanos voltaram para casa sem um novo acordo, assim como ocorreria com outras duas delegações até julho de 1946, quando Cuba suspendeu suas exportações de açúcar.

O secretário de Agricultura dos Estados Unidos viajou para Cuba e terminou por assinar um acordo que aceitava uma garantía de Menéndez (cláusula de garantia) vinculando o preço do açúcar cubano a um índice baseado no preço de um grupo de produtos básicos que Cuba comprava dos Estados Unidos. À Associação de Usineiros, onde todos pareciam prontos a assinar qualquer acordo sob o lema/pretexto "Sem açúcar não existirá país”, Menéndez contrapôs “O

acomodações dos trabalhadores caribenhos junto aos locais do sindicato. Levou o assunto aos líderes do sindicato e eles, em conjunto, apresentaram um protesto diante da Embaixada britânica. $\mathrm{O}$ vice-cônsul visitou as usinas e exigiu que a Cubanaco fizesse melhorias. VILLAFRUELA. El general de las cañas, p. 13.

58 "El diferencial en la punta de la mocha." Essa é a definição do diferencial no coletivo de autores Memorias de un viejo mundo azucarero, p. 216. 
açúcar a serviço de Cuba". ${ }^{59}$ Tratava-se de uma vitória inédita: marcava a primeira vez que um país do "Terceiro Mundo" celebrava um acordo comercial compensatório com uma nação capitalista desenvolvida.$^{60}$ Os trabalhadores do setor açucareiro receberam \$29 milhões da garantía de \$36 milhões distribuída em 10 de dezembro de 1946. Graças à garantía que eles obtiveram no ano seguinte - após outra batalha comum, que uniu trabalhadores e donos de plantações de cana -, os trabalhadores terminaram recebendo salários totais $40,6 \%$ mais altos do que em 1946, a mais elevada remuneração da história da indústria açucareira. ${ }^{61}$

A unidade trouxe à classe trabalhadora, como um todo, mais força para a conquista de suas reivindicações sob as presidências populistas da década de 1940, o mesmo se aplicando aos trabalhadores da cana-de-açúcar. A transformação da FNOA em FNTA, em 1945, levou a meta da "unidade" para a esfera nacional. Numerosos testemunhos salientam o fato de que Menéndez vinha trabalhando em prol desse objetivo durante muitos anos em nível local. Em Chaparras e Delicias, ele havia ajudado a organizar sindicatos tanto nas fazendas de cana quanto nas usinas. Esse sindicato único permitiu que os trabalhadores da Cubanaco conquistassem significativos benefícios para ambos os setores. Os trabalhadores da usina e das plantações de Chaparra referem-se aos meados da década de 1940 como a época em que conseguiram "os melhores contratos coletivos do país". Os trabalhadores rurais conquistaram o direito a terras onde poderiam complementar sua renda e alimentar suas famílias, e os trabalhadores das usinas receberam também um significativo conjunto de benefícios. ${ }^{62}$

\section{A Guerra Fria prejudica o pacto, 1947-1955}

Foi preciso muito tempo para que os trabalhadores do setor açucareiro atingissem essa unidade. Associada ao clima econômico e político favorável aos trabalhadores em fins dos anos 1930 e início dos anos 1940, a unidade permitiu que

59 O lema da Associação dos Usineiros era Sin azúcar, no hay país, e o da FNTA era El azúcar al servicio de Cuba, mas, de acordo com outros trabalhadores, esse lema era Sin trabajadores, no hay azúcar (sem trabalhadores não há açúcar).

60 SIMS “The Cuban sugar workers' progress under the leadership of a black communist”, p. 12.

61 ZANETTI. “The workers' movement and labor regulation in the Cuban sugar industry”, p. 197.

62 Luis Merconchini, entrevista feita por Víctor Marrero, Delicias, 21 ago. 1990; José Rodríguez Alejo, entrevista feita por Víctor Marrero e Olga Cabrera, Chaparra/Delicias, 15 set. 1992, em fita gravada. Oficina del Historiador de la Ciudad de Las Tunas. 
eles desafiassem o poder das empresas e dos plantadores de cana. Mesmo sob as circunstâncias mais favoráveis, era difícil manter uma atitude de solidariedade por causa da cooptação populista das camadas superiores e das divisões ocupacionais (e outras divisões sociais) internas. A investida das políticas da Guerra Fria e do populismo anticomunista a partir de 1947 tornou a unidade ainda menos viável. Os trabalhadores rurais e das usinas de Chaparra, Delicias, Tuinucú e de outras usinas da Ilha uniram-se e separaram-se, em inúmeras ocasiões, no decorrer das décadas de 1940 e 1950.

Em 22 de janeiro de 1948, um capitão do Exército atirou em Jesús Menéndez na plataforma de uma estação de trens em Oriente. Seu corpo foi colocado em um trem para Havana e, à medida que a viagem prosseguia, multidões se postavam em cada estação, de punhos cerrados e gritando: "Unidade, CTC!” Havia milhares de pessoas aguardando também em Havana, e organizações provenientes de todos os países das Américas enviaram telegramas condenando o crime. Cem mil pessoas caminharam do Capitolio até o cemitério de Colón, no dia 25 de janeiro de 1948, após dois dias de vigília. Foi a maior e mais disciplinada concentração de pessoas jamais vista em Havana. ${ }^{63}$

Menéndez havia falado de forma apaixonada sobre a importância de todos permanecerem unidos, e durante muitos anos a FNTA e a CTC haviam conseguido manter essa unidade. Porém, mesmo antes de seu assassinato, a política da Guerra Fria começara a fomentar a divisão. Em 12 de março de 1947, o presidente Harry S. Truman proclamou a "Doutrina Truman", que se propunha "dar apoio aos povos livres que resistiam à tentativa de submissão por parte de minorias armadas ou por pressões externas". Na prática, a forma pela qual os políticos dos Estados Unidos aplicavam a doutrina consistia em ajudar os grupos de oposição a destituir os comunistas da liderança ou de cargos no governo, declarar os partidos comunistas ilegais e canalizar recursos para forças armadas conservadoras. ${ }^{64}$

Contando com o apoio do movimento anticomunista em sua retaguarda, os Auténticos passaram a dirigir seus ataques à liderança comunista nos sindicatos. Tudo começou pelo topo, com o congresso da CTC marcado para ocorrer em abril de 1947 (um mês após a declaração de Truman). A partir de 1947, a atitude do governo com relação ao movimento trabalhista consistiu em abandonar a persu-

63 GALLÓ, Gaspar Jorge García. Esbozo biográfico de Jesús Menéndez. Havana: Política, 1978. p. 150-176. 64 GRANDIN, Greg. The last colonial massacre. 
asão e adotar o recurso da força. Os trabalhadores se recordam - e os registros da Cubanaco confirmam esses fatos - que eles eram detidos com mais frequência do que ocorrera durante o período de 1940-1946. Eram presos por motivos tais como reivindicar o diferencial, ou por tentar organizar reuniões do Unitario CTC em contrapartida à nova CTC dominada pelos Auténticos (os Unitários chamaram essa nova CTC de CTK, que para eles significava "Sindicato dos Fura-Greves"). ${ }^{65}$

Em 1947, o ministro do Trabalho anticomunista de Grau, Carlos Prío Socarrás, legalizou a CTC dos Auténticos sob a liderança de Eusebio Mujal em detrimento da CTC dos Unitarios de Lázaro Peña. Quando a CTC dos Unitarios realizou uma greve geral, Prío mandou prender 115 líderes trabalhistas e incentivou os empregadores a demitir todos os que haviam participado da greve. ${ }^{66}$ Prío chegou à presidência em 1948, e a repressão se intensificou. Evidentemente, em decorrência desse fato, os líderes populistas sob o regime Auténtico de 1948-1952 e do regime Batistiano de 1952-1959 perderam grande parte do apoio popular de que dispunham, já que se assentavam em organizações superficiais e repressoras.

A política da Guerra Fria e a crescente onda de corrupção e violência que grassou sob o domínio dos Auténticos começavam a solapar a legitimidade do Estado, conquistada por meio do pacto populista de 1937-1947. A década de 1940 testemunhou a proliferação de partidos revolucionários violentos que lutavam por cargos apadrinhados, status de membros e "prerrogativas" clientelistas no Congresso, no campus da Universidade de Havana e nas sedes dos sindicatos em todo o país. Muitas das organizações haviam surgido durante a Revolução de 1933, como a Sociedade Revolucionária ABC, a Federação dos Estudantes Universitários (FEU) e a Esquerda Estudantil (AIE em 1930, rebatizada como Diretório dos Estudantes Revolucionários [DRE] sob José Antonio Echeverría na década de 1950).

Fidel Castro participou desses violentos embates quando era estudante de Direito na Universidade de Havana, antes de aliar-se ao partido que os reformistas esperavam ser uma alternativa política viável aos irremediavelmente corruptos Auténticos - o Partido Ortodoxo de Eduardo Chibás. ${ }^{67}$ Chibás, que fora um

65 ALEXANDER, Robert J. A history of organized labor in Cuba. Westport, Conn.: Praeger, 2002. p. 117.

66 SPALDING. Organized labour in Latin America, p. 231.

67 THOMAS. The Cuban revolution, p. 24. 
importante líder estudantil em 1933, rompera com o Partido Auténtico em 1947 para criar o Partido Revolucionário Cubano "Ortodoxo". O nome do partido destinava-se a desacreditar o Partido Revolucionário Cubano "Auténtico", da mesma forma como fazia seu líder ao expor todos os casos de corrupção nos altos escalões do governo. Quando Chibás atirou em si próprio por ocasião de um programa de rádio em 1951, um gesto dramático que culminou com sua morte, deixou muitos cubanos desestimulados. ${ }^{68}$ Os Auténticos pareciam alimentar uma ambição sem limites, e o Partido Ortodoxo não era mais uma alternativa viável sem a liderança carismática de Chibás. Batista agia nos bastidores, desesperado para retomar a presidência e "restaurar" a ordem que os Auténticos haviam rompido. Ele concorreu, ocupando um distante terceiro lugar em relação aos candidatos do Ortodoxo e do Auténtico, às eleições presidenciais de 1952 e tentou um golpe de Estado para evitar a derrota. ${ }^{69}$ Essas conspirações - e sua inexistência durante o período populista de 1940 a 1952 - demonstram a importante função estabilizadora desempenhada pela política eleitoral, mesmo diante de uma situação de corrupção extrema. ${ }^{70}$

O regime de Batista em 1950 diferia em muito do que vigorara em 1940. O fato de os Estados Unidos concederem apoio militar e diplomático a Batista, após sua tomada ilegal do poder, abalou a legitimidade do ditador perante os cubanos de todas as camadas sociais. Ele negociou grandes empréstimos de exportação-importação com o governo norte-americano e envolveu-se em óbvios casos de suborno. Concedeu benefícios tributários aos capitalistas dos Estados Unidos e tentou eliminar algumas conquistas trabalhistas, ostensivamente para atrair mais investidores para a Ilha e impulsionar a economia. Seu regime exigia subornos tão volumosos para esses novos investimentos, que estes acabaram beneficiando muito pouco o povo cubano em geral. Por outro lado, a política da Guerra Fria

68 Um amigo do médico de Chibás contou a um colega que Chibás havia verificado exatamente onde deveria apontar o revólver para executar seu gesto dramático sem correr risco real, mas uma inesperada hemorragia levou-o à morte. Conversa com Marial Iglesias, Toronto, 24 nov. 2006. Para mais detalhes sobre a cultura cubana do martírio, ver PÉREZ JR., Louis A. To die in Cuba: suicide and society. Chapel Hill: University of North Carolina Press, 2005; STONER, Lynne K. "Militant heroines and the consecration of the patriarchal State: the glorification of loyalty, combat, and national suicide in the making of Cuban national identity." Documento apresentado na Conferência da Associação Histórica Americana, Chicago, dez. 2002, p. 71-96.

69 PÉREZ. Cuba, p. 287-288.

70 DOMÍNGUEZ. Cuba, p. 136. 
dos Estados Unidos impedia a possibilidade de uma nova aliança com os comunistas (a popularidade de sua CTC junto à classe trabalhadora não mais existia, destruída que fora pelos anos de dominação desagregadora dos Auténticos). Sem os comunistas para angariar trabalhadores, restou a Batista apenas duas bases de apoio: as forças armadas e os políticos americanos.

\section{A ditadura esvazia o pacto}

O maior problema de Batista na qualidade de chefe de um governo populista na década de 1950 foi não conseguir "equilibrar os grupos da sociedade" quando, na verdade, esses grupos não continham o elemento "sociedade" em grau suficiente. Batista praticava o favorecimento e o nepotismo em tão grande medida, que conseguiu destruir o pouco de integridade ainda existente em instituições populistas como a Associação dos Plantadores de Cana e a CTC. De certa forma, ele representou uma volta à política de favorecimento individualista. Ele e a mulher distribuíram "recursos discricionários" e cargos a pessoas que eles consideravam amigas (como jornalistas e advogados) na tentativa de angariar mais apoio. ${ }^{71}$ Esses poucos favorecidos afastaram a grande maioria dos aliados pertencentes às instituições populistas, ao barrar seu acesso ao Estado e a seus benefícios.

A mesma ausência de democracia campeava nos sindicatos. Essas organizações representavam supostamente um grande número de trabalhadores. Em 1951, pelo menos metade da força de trabalho, ou seja, mais de 1 milhão de pessoas, pagava contribuições sindicais a mais de 2.100 sindicatos. Mas esses números eram ilusórios. Por exemplo, a ampla maioria dos trabalhadores do setor açucareiro não optava mais pelo pagamento das contribuições sindicais diretamente a "seus" sindicatos. Em vez disso, os usineiros e os plantadores de cana deduziam automaticamente essas contribuições dos salários e as distribuíam entre os líderes dos sindicatos locais, da FNTA e da CTC. ${ }^{72}$ As contribuições sindicais estavam despencando desde 1948, e Prío reagiu a isso impondo uma taxa sindical obrigatória a todos os trabalhadores do setor açucareiro (Decreto $n^{\circ} 1.300$, de abril de 1951). Os novos líderes "cooperativos" da FNTA retribuíram o favor de Prío com o enga-

71 Ibid., p. 94.

72 SIMS. "Cuba's organized labour", p. 53. 
vetamento de uma lista de reivindicações elaborada para a colheita de 1952, que incluía um aumento salarial de $40 \% .{ }^{73}$ Em troca do apoio da CTC em 1952, Batista estendeu a obrigatoriedade da taxa sindical a todos os setores trabalhistas. Eusebio Mujal, chefe da CTC (e senador Batistiano), arrecadou comprovadamente mais de $\$ 280.000$ anuais durante o período da ditadura. ${ }^{74}$

Como não conseguia incorporar um número suficiente de pessoas ao regime, Batista, no decorrer da década de 1950, precisou apelar cada vez mais para a violência em lugar da persuasão. Viaturas policiais e guardas montados em imponentes cavalos texanos voltaram a intimidar os residentes nas usinas de açúcar e invadiam constantemente as casas e as assembleias dos trabalhadores à procura de comunistas. Um chefe de departamento chegou a impedir que os membros comunistas da CTC (Unitários) deixassem o local de trabalho durante o horário de votação nas eleições sindicais. Valdívia contribuiu com um detalhe realmente ilustrativo desse relato, que contrasta com o partidarismo das narrativas escritas: "Alguns Unitarios se vendiam, e alguns Auténticos eram honestos."75 Em meados da década de 1950, contudo, o movimento sindicalista oficial estava extremamente comprometido com líderes empresariais e do governo. As contribuições sindicais obrigatórias de Batista tiravam dos trabalhadores qualquer possibilidade de opção de filiação ou não aos sindicatos, fazendo com que os líderes sindicais se sentissem pouco motivados a assumir a responsabilidade.

Desmoralização, corrupção e violência fizeram com que as usinas de açúcar passassem a ignorar ou se opor a muitas das conquistas trabalhistas do período de 1937-1947. Os trabalhadores responderam com greves, paralisações da produção, liderança paralela e sabotagem. O trabalhador José Adan Romero Rojas descreve uma greve ocorrida em 1950 em Chaparra, em que os operários da fábrica reivindicavam o pagamento de bônus pelos dias que teriam trabalhado caso as transformações tecnológicas introduzidas na usina e a consequente rapidez de produção proporcionada por elas não lhes tivesse subtraído esses dias. Tratava-se de um protesto não muito diferente daqueles que cercaram o "taylorismo",

73 ZANETTI. "The workers' movement and labour regulation in the Cuban sugar industry", p. 199.

74 SPALDING. Organized labour in Latin America, p. 233.

75 Eladio Santiago Serrano e Arquímedes Valdivia Hernández, entrevista com o autor, Tuinucú, 12 maio 2000. Rita Díaz, entrevista com o autor, Havana, 10 set. 2006. 
quando se exigia, em toda a América, que os trabalhadores executassem tarefas mais meticulosas e com maior rapidez. ${ }^{76} \mathrm{~A}$ liderança sindical apresentou suas exigências ao ministro do Trabalho, mas “o arrogante Mister Wood” manteve-se intransigente.

O sindicato precisava do apoio unânime dos trabalhadores para vencer, mas não estava autorizado a realizar reuniões durante o período da colheita. $\mathrm{O}$ sindicato "consultou as massas" por meio de pequenos grupos, em várias sessões nas cidades onde se localizavam as usinas. Seus representantes explicavam o plano que a liderança paralela do Unitario da CTC estava defendendo em Havana - o paso de jicotea (ou "passo de tartaruga"). Essa ação demonstrava a força do sindicato e o grau de hostilidade dos trabalhadores para com a empresa estrangeira. O pagamento pela produção mais rápida não podia ser ganho com corpo mole, portanto os trabalhadores passaram a abandonar a fábrica, deixando apenas o que Adan chamava de "inimigos da classe operária, os fura-greves submissos e covardes". ${ }^{77}$ Esses fura-greves eram na verdade trabalhadores rurais trazidos pela Guarda Rural. Uma vez que a tecnologia contra a qual reagiam os operários não afetava os trabalhadores rurais, o sindicato deixou-os de fora das discussões, o que foi, sem dúvida, um erro. A administração tentou recorrer ao suborno para fazer com que os líderes sindicais se mantivessem longe do Ministério do Trabalho, e, quando isso não funcionou, apelou-se para as ameaças de morte. Mas nada disso adiantou: no dia 29 de março de 1950, após mais de seis horas de discussões entre os líderes sindicais e a "administração yanqui", o presidente Prío assinou o Decreto $\mathrm{n}^{\circ} 1.931$, assegurando seis dias de pagamento de bônus a todos os trabalhadores do setor açucareiro do país. ${ }^{78}$

A exigência do pagamento de bônus tem estreita ligação com uma série de outras reivindicações apresentadas pelos trabalhadores na tentativa de solucionar o maior problema de Cuba: o desemprego. A violência e a corrupção contribuíram de forma significativa para explicar por que houve uma revolução em Cuba nos anos 1950, mas o principal problema estrutural em 1959 era o mesmo obser-

76 Ver FARNSWORTH-ALVEAR. Dulcinea in the factory; KLUBOCK. Contested communities; MONTGOMERY. Workers' control in America; e WINN. Weavers of revolution.

77 ROJAS, José Adan Romero. A través de mis recuerdos. Jesús Menéndez: Casa de Cultura José de la Luz y Caballero, 1985. p. 10-11.

78 Ibid., p. 10-13. 
vado em 1933: a dependência de um produto que exigia um grande número de trabalhadores durante somente alguns meses no ano. $\mathrm{O}$ tratado de reciprocidade de 1934 só exacerbara o problema, reduzindo as possibilidades de emprego para a classe operária e também para a classe média. Um antigo trabalhador da usina de açúcar Violeta, Angel Santana Suárez, descreve em cores vivas o desemprego dos anos 1950:

Era comum ver centenas de companheiros andando pelas ruas, no início de cada período de colheita, carregando seus objetos pessoais em cestos de palha, pedindo a ajuda dos sindicatos para conseguir trabalho. Quantas vezes eles nos pediram para deixá-los cortar um pouco de cana, para que pudessem continuar a seguir seu caminho, ou deixá-los trabalhar por metade de um dia em troca de "água e carvão"! Centenas, milhares de vezes! ${ }^{79}$

Os trabalhadores lutavam - chegando mesmo a apelar para a Suprema Corte - contra o tipo de demissão que os patrões insistiam em classificar como "justa causa". Os usineiros tentavam - e às vezes conseguiam - "comprar" as vagas dos trabalhadores, oferecendo-lhes dinheiro para não retornarem na próxima colheita. Os trabalhadores lutaram com unhas e dentes contra qualquer forma de mecanização, resistindo aos tratores nos canaviais e aos contêineres (em substituição às sacas) nas docas. As leis populistas e a Constituição de 1940 protegiam, até certo ponto, os empregos dos trabalhadores, isso até o golpe de Batista. Mas, de acordo com um economista norte-americano que pesquisava as relações trabalhistas pouco antes da Revolução de 1959: "Desde 1953, a interpretação das leis de 1933 tem sido muito mais leniente." Ele observou que as greves só eram toleradas após o aviso prévio de 10 dias ao Ministério do Trabalho e garantia aos investidores que a tática de "intervenção" usada frequentemente durante os anos do Auténtico para obrigar as empresas a atenderem às reivindicações trabalhistas não era aplicada desde 1953. E acrescentou: "As rígidas atitudes adotadas pelos sindicatos e pelos governos no passado tornaram-se muito mais brandas." ${ }^{80}$ Sua escolha das palavras refletia uma opinião que os usineiros e os plantadores de

79 EWELL, Judith. Angel Santana Suárez: Cuban sugar worker. In: BEEZLEY, William H.; EWELL, Judith. The human tradition in Latin America: the twentieth century. Lanham, Md.: Scholarly Resources, 1998. p. 75-88, especialmente p. 87.

80 NEWMAN, Philip C. Cuba before Castro: an economic appraisal. Ridgewood, N.J.: Foreign Studies, 1965. p. 15. 
cana seguramente compartilhariam. Na ótica dos trabalhadores, os sindicatos não eram "brandos”, mas inúteis.

A partir de meados dos anos 1950, com o endurecimento da ditadura, os trabalhadores passaram a adotar as estratégias de greve geral e de sabotagem de que haviam lançado mão em 1933. Em dezembro de 1955, dois operários, Conrado Rodríguez e Conrado Béquer, organizaram o que ficou conhecido como a "greve dos Conrados", com a ajuda paralela da CTC Unitário e dos estudantes de classe média pertencentes à organização Directorio Revolucionário. Foi uma das maiores greves dos trabalhadores do setor açucareiro da história de Cuba, envolvendo cerca de 500 mil pessoas, apesar das advertências contrárias da CTC Auténtico e da FNTA.

Os trabalhadores exigiam o fim das restrições sobre as colheitas do açúcar, o pagamento com base em um preço fixo de cinco centavos por cada libra-peso e um diferencial igual a $8 \%$ dos salários dos trabalhadores (os plantadores de cana e os usineiros, com a ajuda do Icae, tentaram eliminar o diferencial, ocultando os lucros em suas práticas contábeis). Os trabalhadores conseguiram paralisar mais de 15 usinas, como a de Tuinucú, mas o Exército de Batista os reprimiu de forma violenta em Chaparra, Delicias e em todas as demais localidades da Ilha, no episódio que ficou conhecido como Natal Sangrento. Batista terminou por conceder um diferencial aos trabalhadores, mas de apenas 1\%, em vez dos $8 \%$ reivindicados. Batista, Mujal e os líderes da FNTA foram comprados pelos usineiros e plantadores de cana em 1955, assim como Grau fora comprado pela U.S. Credit Corporation em 1948, quando concordou em anular a cláusula de garantía de Menéndez. ${ }^{81}$

A CTC e a FNTA, instituiçõos populistas que outrora haviam funcionado como importantes ferramentas para as novas "classe operária" e a "classe dos trabalhadores no setor açucareiro", como se autodenominavam, tornaram-se veí-

81 A greve do açúcar de 1955 é uma opção promissora para futuras pesquisas quando outras fontes governamentais se tornaram disponíveis no que diz respeito à década de 1950. Ver BONACHEA, Ramón L.; SAN MARTÍN, Marta. The Cuban insurrection 1952-1959. New Brunswick, N.J.: Transaction Books, 1974; BORY, Pedro Cardona. La huelga azucarera de diciembre de 1955 y la alianza obrero-estudiantil. Havana: [S.l., s.d.]. Gladys Marel García-Pérez acentua a importância das greves e dos atos de sabotagem dos trabalhadores do setor açucareiro (e outros) em Matanzas e em outras partes da Ilha em Insurrection and revolution: armed struggle in Cuba, 1952-1959 (Boulder: Lynne Reinner Publishers, 1998), seu estudo de caso provincial de 1950 em Matanzas que analisa o porquê do triunfo do movimento de Fidel Castro em 1959. 
culos para o enriquecimento pessoal de uns poucos indivíduos. A greve de 1955 que os trabalhadores organizaram, a despeito das determinações em contrário da CTC e da FNTA, ajudou a demonstrar como a ditadura e o clientelismo haviam fragilizado uma das mais sólidas edificações populistas de Cuba. 